\title{
The North-South Dialogue As A Panacea For The Development Of The South: How Realistic?
}

\author{
Tandu, Egbe Ojong(Ph.D) Ogon, Sunday Offum(Msc.) Etta, Peter Tawor (MA) \\ Department of Political ScienceCross River State College of Education.Akamkpa
}

\begin{abstract}
In the context of the quest for a New International Economic Order (NIEO), the so called South found itself in a disadvantaged position hence, the initiation of the North-South dialogue. At long last the countries of the world are coming seriously to grips with the growing material inequalities between a handful of affluent nations of the North America, Western Europe and Industrialized Asia and the scores of poor countries in Less developed Asia, Africa and Latin America which constitute the bulk of humanity but enjoy very little of the earth's bounty. Amuzegar, J. (2000). The North-South dialogue refers to the process through which the developing and new independent nations of the South, predominantly in Less developed Asia, Africa and Latin America, engaged the industrialized countries of North America and western Europe in negotiation over changes in the International Economic System in order to achieve development. The question is, how realistic is that dialogue? This paper therefore examines the reality in this dialogue by first of all looking at the old order, the demands in the new order were also highlighted and critically analysed to see how realistic the demands are in the light of the new order. It concluded by attempting to suggest the way out. The paper adopted a historical/ descriptive and prescriptive approach.
\end{abstract}

Keywords: - North-South, Dialogue, Development, Panacea, Realistic.

\section{INTRODUCTION}

The pre-occupation of European powers with their own affairs and the considerable use of resources on two world wars, the Korean and Vietnam wars and the cold war meant a corresponding neglect of major world problems especially world inequalities. Both the United States of America and the former Soviet Union failed to convinced many newly independent countries that they really cared about, the non-white world,(Kocher, 2000).

The conflict in terms of interest between the poor developing nations living in the southern Hemisphere and the rich industrial countries of the North has entered a new phase in recent times. According to Amuzegar, (2006), at long last the countries of the world are coming seriously to grips with the growing material inequalities between a handful of affluent nations of the North America, western Europe and industrialized Asia (which account for less than 18 percent of the world population but more than 60 percent of world income), and the scores of poor countries in less developed Asia, Africa and Latin America which constitute the balk of humanity but enjoy very little of the earth's bounty.

The United Nations Organization has become the meeting point for the newly independent countries after 1945. An important organ of United Nations Conference on Trade and Development (UNCTAD) formed in 1964 as part and parcel of the United Nations General Assembly became a platform for the developing and new independent nations of the world to be heard. From this time, the south started to campaign in earnest for reforms of the international Economic system. (Blackmer, 2000).

The North-South Dialogue refers to the process through which the developing and newly independent nations of the south, predominantly in Asia, Africa and Latin America, engaged industrialized countries of North America and Western Europe in Negotiations over changes in the international Economic system some decades ago. According to the United states Department of state Achieves January $20^{\text {th }}$, 2001, after the second World War (WWII) many nations of LatinAmerica became increasingly frustrated with United States trade and tariffs policies. At the same time, Nationalist movements in Asia and Africa helped lead to widespread decolonization. Membership in United Nations had risen from 51 countries in 1945 to 100 in 1960 and 150 by 1979 and recently almost 160 .

The sudden influx of new countries changed the balance of power in the General Assembly and made possible the establishment of UNCTAD in 1964. UNCTAD created a forum through which the "South" could propose economic policies, engaging industrial democracies of the "North". The term "North-South Dialogue" was used to distinguish the dynamic from the East -West conflict of the cold war, and also stress the point that development issues were just as pressing as the ideological conflict between communists and capitalists. (Mikias, 2010). 
The newly industrializing Economies, meanwhile, believed the entrenched international Economic system benefited developed countries at the expense of the developing world. They help to facilitated a reorganization of International Economic system to rectify this imbalance. The North-South Dialogue addressed issues pertaining to trade and tariffs, international finance, foreign aid, and the governance of multinational companies and institutions. (Amuzegar, 2001). The North-South Dialogue can also be viewed as a political struggle between the world "haves" and "have-nots" in this view, the discussion became a vehicle through which the south could unite and assert power within the United Nations and other International Organizations to counter the abilities of the North to dictate the course of world affairs. (U.S.A. gov.)

\section{THE OLD WORLD ORDER}

The structural division of the world is not natural. It is a deliberate, necessary and definite design of Western capitalism, spanning through the period of expropriation (Slavery), colonialism and neo-colonialism, (Amin, 1975). The North is made up of centre-nations of the worldwhose economies are dominant, selfreliance or auto centric and old. They are also technologically advanced and strong. Such countries are in North America, Europe and Industrialized Asia. The south has been peripheralized and is dependent, dominated, unindustrialized and weak. These include countries in Latin America, Africa, backward Asia and Middle East, (Mikias, 2010). Capitalism as an international economic system produces goods not for use or needs but for profit and continues to follow its inevitable and survivalist logic of expansion. According to (Aluko, 1977), this kind of system is pregnant with inherent contradiction and crisis due to the fact that wealth is produced by many but monopolized by a few. In order to neutralized capitalism in Europe and guarantee external markets, sources of raw materials and profitable investment avenue capitalism expanded into developing areas and restructured these developing areas to fit into the European economic system as appendages or satellites, (Rodney, 1972). Thus, an international division of labour was created between the North and the South, and rationalized in bourgeois economic theories of comparative advantage (a country has comparative advantage in the production of a commodity in which its absolute advantage is greater or absolute disadvantage is less) and comparative cost (a country should export those commodities which it can produce at relatively low cost and import those commodities which it can produce at relatively high cost) both of which encourage the south to specialized in primary production and reduce their economies (Daniel, 1980).

The management of the World economic system was in the $20^{\text {th }}$ century codified in the Brettonwoods system (1944) Amin (1977) which concentrated huge economic and political power in the centre nations of the North enabling them to assume a leadership role in international economic system through the manipulation of the activities of the Multinational Corporations and International Organizations like the United Nations Organization (UNO), and its parasubsidiary organs like the world bank and International Monetary Fund (IMF). The structure ofunequal relations between North and south creates development in the North and simultaneously produce underdevelopment in the south. Development and underdevelopment therefore are two sides of the same coin and aspects of the same historical process. (Daniel, 1980).

Under the umbrella of the United Nations Organization conference on Trade and Development (UNCTAD), the south initiated a dialogue with the North to restructure the political and economic relations between them to be equal and to bridge the widening gap between the developed and the developing countries and to create a New International Economic Order (NIEO) based on the mutual interest of all. The essence is to enable the south to initiate internally located and relatively autonomous development to reduce mass unemployment, chronic poverty and pathological dependence.

\section{THE NEW ORDER OF THE WORLD}

The Issue or Demands inthe North-South Dialogue to Bring about New International Economic ORDER (NEO)

1. Transfer of technology from the North to the South.

2. Economic Cooperation between the south based on complementarily (Mutual interest) that is south-south cooperation.

3. Restructuring of international trade to reduce unequal exchange and Northern protectionism.

4. Fair prices for exports and reduction of eratic price fluctuation.

5. Industrialization of the south to diversity the southern economy and reduce the monoculture division of labour and.

6. Repudiation (to cancel) or re-scheduling of the south external debt. (U.S. Department of state Aehives, 2001). 


\section{A CRITIQUE OF THE NORTH-SOUTH DIALOGUE AS REGARDS TO THE ITS REALITY DEVELOPMENT OF THE SOUTH}

The demand for a New International Economic Order (NEO) is based on a misconception of the system called imperialism on the part of the comprador element in the south. This is alsoa reflection of the false consciousness and reformation of the leadership of the south. They believed that the world can be reformed out of the better ideas springing from idealist philosophy of the bourgeois of the Neo-Kertian era or moralism. The belief refused to face reality but run after the shadow. The south now want an economic earthquake to shake the old order to its very foundation because of the following factors.

The New International Economic Order (NIEO) demands recognition of the right of each over its wealth and this only reaffirm the law providing permanent sovereignty over natural resources. In the case of Nigeria, it means Nigeria has the right to regulate foreign capital, control Multinational Corporations and nationalize foreign properly, but this is not something new because it exist only in principle, in practice it is a crippled rule.

The New International Economic Order (NIEO) called for the right of the state to farm commodity arrangement for stable price liberalization of world trade and improvement of prices for primary products. This struggle has been under the umbrella of United Nations Conference on Trade and Development (UNCTAD), General Agreement on Tariff and Trade (GATT) and International Monetary Fund (IMF)but for more than 30 years nothing has been achieved.

The New International Economic Order (NIEO) called for all states to enjoy the benefit of technological advancement or transfer. That is the North should give the south their technology. This is a dream because technology is monopolized by multinational corporations and cannot be transferred to the south in a process of code of conduct laid down in the NewInternational Economic Order.

The south called for non-discriminatory tariff preference, but we know that the North practice a lot of protectionism and avoid competition from the south. The south called for more aids on better terms but we known that officially aids from the North has fallen instead of increasing to $80 \%$ as demanded by United Nations Conference on Trade and Development (UNCTAD), (Kochler, 2000).

The south called for cancellation or rescheduling of the world debt, but as at now the south is paying back to the North more than it is expected to received from the North as reported by Times international Edition of $10^{\text {th }}$ May, 2003.

The General Assembly of United Nations Organization resolution calling for cooperation between the North and South assumed that the prosperity of the North is positively related to the development of the south. This pretention misled the UNO to suggest cooperation based on sovereign equality of states. But the fact is that the cooperation of the North and South is a relationship between a cat and a mouse or master and servant. This is because it is based on unequal relations that leaves the world as a heterogeneous entity of rich and poor countries, therefore, there is a transparent contradiction in the UNO efforts to solve the backwardness of the south, because of the adoption of instrument whose inevitable consequences are the repetition and aggravation of the peripheralization of the south, (Daniel, 2001).

It must be noted that the United Nation is not a neutral institution but a minor of the unjust order and can do nothing to change the object it reflects. These demands cannot lead to any fundamental change because they reflect the same old order. In the present era, where monopoly capitalism has assumed a highly integrated level, it is a sure illusion to expect multinational corporations to relax the Gross National Product (GNP) they have established over the south so many years age, (Amuzegar, 2000).

\section{THE WAY OUT}

The North-south debate or dialogue must not be used as an escapist ploy by the leaders of the south for failing to deal with internal development problems. Development must be seen as a national issue, a problem of transforming domestic social, economic and political structures. Emphasis must be on our self reliance development more than looking outward. Development at a national level and collective self reliance and to a collective autonomy within the south. Emphasis must be on unconditional decolonization and disengagement from the capitalist system. Any relationship should be on mutual terms of we have to relate at all. All the countries in the south should re-organize the societies to reflect genuine, popular, honest, dedicated, selfless leadership which see their destiny as that of the poor majority and should be supreme. It is only when the south employ unvaried looking strategies and develop sound independent national economies that they can participate in international economy as equal with the North. 


\section{CONCLUSION}

The North-South dialogue was a strategy by the south who took advantage of the path way created by the United Nations Organization by establishing United Nations Conference on Trade and Development (UNCTAD) to chat a process of their development. It was a lofty idea, but the structure of the world definitelycannotallow it work. It is an unjust structure and anything based on that can only reflect the same unjust result. The south need to adopt varied strategies and must especially look inward to chat the path for the development of the south. Negotiation with the North cannot guarantee development in the south.

\section{REFERENCES}

[1] Aluko, O. (1977). The foreign Policies of African States (Ed). London: Holder and Stoughton.

[2] Amin, S. (1975). "The Economic Order". Reaction of the Developed World strategy of the use of surplus of certain developing countries. Dalear, UNATEDP.

[3] Anulrzegar, J. (1976). The North-South Dialogue: From Conflict to compromise. U.S.A. Texas.

[4] Daniel, O. A. (1980). Imperialism and Dependency Enugu Nigeria, Fourth Dimension Publisher.

[5] Kochler, H. (2000). Globility versus Democracy. The changing International Relations. London, Madonald and Evans.

[6] Mikias, P. (2010). Developing the Global South: A UN Prescription for the South. U.S.A. Algora Publisher.

[7] Rodney, W. (1975). How Europe Underdeveloped Africa. Enugu-Nigeria, Ikenga Publisher.

[8] Times International Edition, 10 ${ }^{\text {th }}$ May, 2003. U. S. Department of state Achieves, 2001. 